\title{
Role of Nasal Endoscopy for the Evaluation of Epistaxis
}

Dr. Md. Mukhlesur Rahman ${ }^{1 *}$, Dr. Mojibul Haque Khan², Dr. Mostafa Mahfuzul Anwar ${ }^{3}$, Dr. Mahmuda Begum ${ }^{4}$

${ }^{1}$ Assistant Professor, Dept. of Otolaryngology- Head and Neck, Surgery, Chittagong Medical College, Chattogram, Bangladesh

${ }^{2}$ Professor and Head (Ex), Dept. of Otolaryngology- Head and Neck, Surgery, Chittagong Medical College, Chattogram, Bangladesh

${ }^{3}$ Professor and Head, Dept. of Otolaryngology- Head and Neck, Surgery, Chittagong Medical College, Chattogram, Bangladesh

${ }^{4}$ Assistant Professor, Dept. of Pathology, Chittagong Medical College, Chattogram, Bangladesh

*Corresponding author: Dr. Md. Mukhlesur Rahman

Abstract

Objective: In this study our main goal is to evaluate the role of nasal endoscopy for the evaluation of epistaxis. Method: This cross-sectional study was conducted among 50 patientswho fulfilled criteria from department of otolaryngology-Head and neck surgery, Chittagongmedical College and hospital, chattogram from January 2017 to January 2019. Results: During the study, most of the patients belong to 41-50 years age group, 36\%. 10\% had nasal polyp, 26\% had DNS, septal spur with ulceration, and 30\% had bleeding point high in lateral nasal wall crevices. $38 \%$ treated with endoscopic nasal packing. Followed by $10 \%$ treated with endoscopic polypectomy, $26 \%$ treated with endoscopic nasal cautery. Conclusion: From our study we can conclude that, a nasal endoscope is the only hope to prevent trauma to the normal mucosa due to these packing materials and Instruments. Further study is needed for better outcome.

Keywords: Nasal endoscopy, epistaxis, otolaryngology.

Copyright @ 2020: This is an open-access article distributed under the terms of the Creative Commons Attribution license which permits unrestricted use, distribution, and reproduction in any medium for non-commercial use (NonCommercial, or CC-BY-NC) provided the original author and source are credited.

\section{INTRODUCTION}

Epistaxis is one of the common symptoms encountered in the otolaryngology. Many times, the cause for epistaxis is not found on anterior and posterior rhinoscopy. It is a common clinical condition and not a specific disease process, but it is essentially a symptom complex. It is the most frequent emergency in Otolaryngology, presenting with a prevalence of about $10 \%$ to $12 \%$ [1-3]. Most of the time, it is able to locate the cause or the bleeding point. One of the principal reasons being the poor visualization of the covert areas of the nose, which are situated in the deep crevices of the lateral wall of the nose. Anterior and posterior rhinoscopy thus, has its limitations. In this study our main goal is to evaluate the role of nasal endoscopy for the evaluation of epistaxis [4].

\section{OBJECTIVE}

General objective

- To assess the role of nasal endoscopy for the evaluation of epistaxis.

\section{Specific objective}

- To detect abnormalities found in nasal endoscopy.

- To identify endoscopic management of epistaxis.

\section{Methodology}

\begin{tabular}{|l|l|}
\hline Type of study & Cross-sectionalstudy \\
\hline Place of study & Department of otolaryngology-Head and neck surgery, chittagongmedical college and hospital, chattogram. \\
\hline Study period & January 2017 to January 2019. \\
\hline Study population & 50 patients included in the study who were fulfilled criteria. \\
\hline Sampling technique & Purposive \\
\hline
\end{tabular}

\section{Study procedure}

During the study, face to face interview of the participants were conducted with the semi-structured, pre-tested questionnaire. The interview was conducted anonymously and privately as much as possible. Before preceding the data collection, the detail of the study was explicitly explained to each eligible respondent and informed written consent from the respondents were obtained. 


\section{Data Analysis}

Descriptive statistics were presented with relative frequency and percentage.

\section{RESULT}

In table-1 shows age distribution of patients where most of the patients belong to 41-50 years age group, $18(36 \%)$. The following table is given below in detail:

Table-1: Age distribution of patients

\begin{tabular}{|c|c|c|}
\hline Age group in years & Frequency & Percentage (\%) \\
\hline$\leq 20$ & 5 & 10 \\
\hline $21-30$ & 7 & 14 \\
\hline $31-40$ & 5 & 10 \\
\hline $41-50$ & 18 & 36 \\
\hline $51-60$ & 11 & 22 \\
\hline $61-70$ & 4 & 8 \\
\hline Total & 50 & 100 \\
\hline
\end{tabular}

In figure-1 shows distribution of patients according to the gender where (29) $58 \%$ patients were male, which was $16 \%$ higher than female (21) $42 \%$. The following figure is given below in detail:

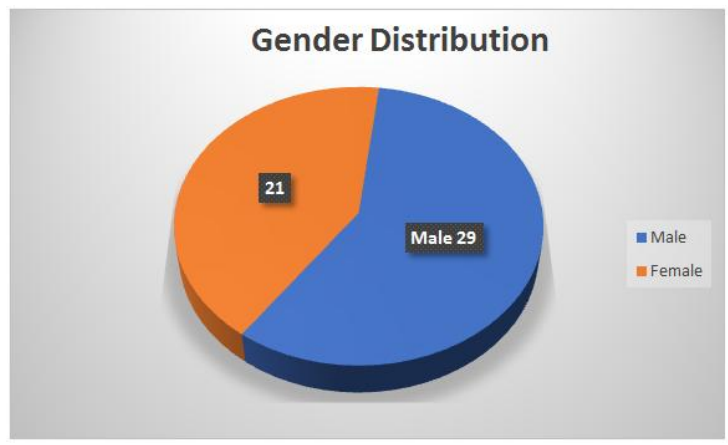

Fig-1: Distribution of patients according to the gender

In table-3 shows abnormalities found in nasal endoscopy. Where $15(30 \%)$ has bleeding point in the crevices of lateral nasal wall followed by $13(26 \%)$ had
DNS, Septal spur with ulceration. The following table is given below in detail:

Table-3: Endoscopic diagnosis

\begin{tabular}{|l|c|c|}
\hline Diagnosis & Frequency & Percentage (\%) \\
\hline Bleeding point in the crevices of lateral nasal & 15 & 30 \\
\hline DNS, Septal spur with ulceration & 13 & 26 \\
\hline Nasal Polyp & 5 & 10 \\
\hline Enlarge adenoids & 5 & 10 \\
\hline Scabs or crust in crevices in lateral nasal wall & 6 & 12 \\
\hline Angiofibroma & 2 & 4 \\
\hline No significant cause & 4 & 8 \\
\hline Total & 50 & 100 \\
\hline
\end{tabular}

In table-4 shows endoscopic management of epistaxis. $19(38 \%)$ treated with endoscopic nasal packing. Followed by $13(26 \%)$ treated with endoscopic cautery or diathermy. The following table is given below in detail:

Table-4: Endoscopic management of epistaxis

\begin{tabular}{|l|c|c|}
\hline Endoscopic management & Frequency & Percentage (\%) \\
\hline Endoscopic nasal cautery or diathermy & 13 & 26 \\
\hline Endoscopic nasal packing & 19 & 38 \\
\hline Endoscopic polypectomy & 5 & 10 \\
\hline Adenoidectomy & 5 & 10 \\
\hline Nasal douching & 6 & 12 \\
\hline Excision of angiofibroma & 2 & 4 \\
\hline Total & 50 & 100 \\
\hline
\end{tabular}




\section{DISCUSSION}

Epistaxis is one of the commonest ENTemergencies. Prevalence of the disease can be up to60\% of the general population [5, 6]. Malepatients are more prone to be affected [7, 11, 12]. Which is supported by our studies where $58 \%$ patients were male and $42 \%$ were female.

Usually epistaxis is spontaneous, mild andstops spontaneously following pinching ofexternal nose (Hippocratis method), but itmay occur following nose blowing andstrenuous work. Sometimes it may beprofuse which can lead to haemodynamicunstability requiring urgent interference. Epistaxis can be divided into two types, anterior and posterior, depending upon thesource of bleeding anterior or posterior topyriform aperture. Usually, anterior epistaxisis commonly seen in young populationand posterior epistaxis is seen in oldpopulation. ${ }^{9}$ In our study, we found that, most of the patients belong to 41-50 years age group 36\%, similar findings was seen in one study[11].

In one study they found that, between 70 $80 \%$ of all cases of epistaxisare idiopathic, spontaneous bleeds withoutany proven precipitant or casual factor. This type is called primary epistaxis. Whereas, when a clear and defined causeof epistaxis is found, then it is calledsecondary epistaxis [7].

Nasal endoscopy takes an important role inevaluating the epistaxis. It helps to revealthe hidden pathologies inside the nasalcavity that can be missed during theanterior and posterior rhinoscopy. It is notalways possible to detect the pathology ofnasal cavity by anterior and posteriorrhinoscopy. Moreover, posterior rhinoscopyis very difficult in most of the cases due toexcessive gag reflex. So, pathologies forposterior epistaxis remains undetected byconventional examination. Nasal endoscopyhelps to detect those pathologies insidenasal cavity that can be easily missed byclinical examination [10]. In our study we also identified that, $10 \%$ had nasal polyp, $26 \%$ had DNS, septal spur with ulceration, $30 \%$ had bleeding point high in lateral nasal wall crevices, similar findings was seen in one study[13]. Most of these diagnosed cases were managed successfully by endoscopic nasal packing $38 \%$, and by endoscopic nasal cautery or diathermy $26 \%$, similar finding was seen in one study [14].

\section{CONCLUSION}

From our study we can conclude that, a nasal endoscope is the only hope to prevent trauma to the normal mucosa due to these packing materials and Instruments. Further study is needed for better outcome.

\section{REFERENCES}

1. Vershney S, Saxena RK. Epistaxis- aretrospective clinical study. Indian JO tolaryngol Head Neck Surgery 2005; 57: $125-5$.

2. Nwaorgu OGB. Epistaxis - an overview. Ann Ibadan Postgrad med. 2004; 1: 1597- 627.

3. Kucik CJ, Clenney T. Management ofepistaxis. Am FAM Physician. 2005; 71:305-11.

4. Viehweg TL, Robertson JB, Hudson JW. Epistaxis: diagnosis and managementand treatment. J Oral MaxillofacSurg. 2006; 64: $511-8$.

5. Abbas N, Hussain I, Amjad M, Akthar FP. Etiological incidence of epistaxis invarious age and sex groups in mayohospital, Lahore. Ann King Edward Med Coll. 1998; 4: 18-9.

6. Ahmed I, Raza SN, Bashir T, Arshad M. Paediatric epistaxis. Pak Postgrad Med J. 2000; 11: 106 - 8.

7. Stell PM. Epistaxis. Clinical Otolaryngology. 1977; 2: $263-73$.

8. Hazarika P, Nayak DR, Balakrishnan R, Raj G, Pillai S. Endoscopic and KTP laser-assisted surgery for juvenile nasopharyngeal angiofibroma. American journal of otolaryngology. 2002 Sep 1;23(5):282-6.

9. Mann WJ, Jecker P, Amedee RG, and Juvenileangiofibromas: Changing surgical concept over thelast 20 years. Laryngoscope. 2004; 114: $291-3$

10. Jorissen M, Eloy P, Rombaux P, Bachert C, Daele J. Endoscopic sinus surgery for juvenile nasopharyngeal angiofibroma. Acta oto-rhinolaryngologica belgica. 2000;54(2):201-19.

11. Vanshney S, Saxena RK. Epistaxis: A retrospective clinical study.2005;5(2):125-129

12. Almeida GS, Diógenes CA, Pinheiro SD. Nasal endoscopy and localization of the bleeding source in epistaxis: last decade's revolution. Brazilian journal of otorhinolaryngology. 2005;71(2):146-8.

13. Vinay Kumar MV, Raghavendra Prasad KU, Belure Gowda PR, Manohar SR, Chennaveerappa PK. Rigid nasal endoscopy in the diagnosis and treatment of epistaxis. Journal of clinical and diagnostic research: JCDR. 2013 May;7(5):831.

14. Babu DMM, Gowda DB, Satish DHS. Role of rigid endoscopy in the diagnosis and management of epistaxis.2014;13(3):40-45. 